\title{
Career Planning and Career Management: Case on Workforce in Makassar
}

\author{
Shinta Dewi Sugihartia,*, Nadya Septiani Sahasa ${ }^{a}$, Sri Ulfaa ${ }^{a}$, Nurfadillaha ${ }^{a}$ \\ ${ }^{a}$ Faculty of Economics and Business, Universitas Hasanuddin
}

\begin{abstract}
Every employee has a career goal he or she wants to achieve. In achieving his or her career, an employee will explore all available opportunities. Career planning is an effort made by individuals in setting goals or achieving desired career goals. This includes activities such as analyzing the abilities possessed, interest in work, values, to identify goals that need to be achieved in supporting the desired career. Looking at the current reality, many companies are experiencing changes caused by the coronavirus pandemic. This problem is felt not only by companies but also by employees because it can hinder their careers. This research is expected to provide insights on individual career planning and the role of organization in career management. This study shows there is a significant relationship between career planning and career management.
\end{abstract}

Keywords: career planning, career management, career goals

\section{INTRODUCTION}

One of the challenges facing organizations in the globalization era is how to deal with change. Every day, managers in organizations face rapid changes due to intense business competition in creating new innovations. In other words, organizational change is inevitable in a dynamic business context. Forces of change include the nature of the workforce, technology, economic shocks, competition, social trends and world politics (Robbins and Judge, 2017).

The world now is facing the biggest change caused by the coronavirus disease pandemic also known as Covid-19. It affects every aspect of the economy worldwide. Employment and jobs are tremendously affected because of Covid-19. The changing nature of work includes layoffs, job sharing, working from home and modifying working hours due to the pandemic (OECD, 2021). Additionally, ILO (2021) reported in 2020 working-hour losses were close to four times greater compared to the 2008 global financial crisis. As a result, this unpredictable outbreak impacted the careers of many individuals.

To adapt to the changing environment, Hamouche (2021) postulates that by involving employees during organizational change will ensure organizational success. As a matter of fact, HR managers should work closely with managers and employees to transform the Covid-19 crisis into opportunities. Equip-

*Author in correspondence,

Email address: (Shinta Dewi Sugiharti)

ISSN: 2549-3221 (Print) 2549-323X (Online)

DOI: $10.26487 /$ hebr.v5i2.3133 ping employees with the right knowledge, skills and attitude is necessary for an organization so as to gain competitive advantage over its competition. Having highly talented employees not only benefits the organization, but also brings benefits to its employees as it is seen as an opportunity to develop their career. As pointed out by (George and Jones, 2012) when careers are properly managed employees feel motivated to perform at high levels, and in the process, organizations can capitalize on their employees' skills and abilities to achieve the company's goals.

In the 20th century, lifetime employment used to be ideal for most people. However, in the turn of the 21st century career preferences began to shift where individuals not only seek career opportunities internally but also externally. The reason for this is as time progresses job mobility has changed an individual's career perception (Weng and McElroy, 2010).

Career is an essential part of someone's employment journey. In general, individuals have preferred career goals that he/she wants to achieve. In order to achieve those goals, an individual will have to explore all opportunities available to them. According to the 2015 Michael Page Indonesia Employee Intention Survey, 72 percent of employees who participated in the survey have the intention to resign from their current job to explore wider career opportunities. Furthermore, the survey results also show the average length of service of Indonesian employees vary, with 24 percent of respondents indicating that they will stay with their current employer for two years or less and another 22 percent saying they will stay for three years or less. This shows that there is a tendency not to stay with a company for a long period of time (Page, 2015).

This phenomenon indicates employers must strategize to re- 
tain their top talents. One strategy for retaining employees is providing them career opportunities within the organization. To use career opportunities as a motivational tool, both employers and individual employees must actively engage in career management (George and Jones, 2012). In this case, the organization has an important role in determining career management practices that are appropriate and needed by employees. Career management is an effort or process carried out by an organization in preparing, developing, implementing and monitoring individual career planning in an organization's career development system (Snell and Bohlander, 2013).

The existence of career management practices that are in accordance with the needs of the organization and employees can be seen as a support made by the organization towards the career development needs of employees. Thus, the perception of support from the organization in employee career development is considered to be able to strengthen employee emotional attachment which then has an impact on increasing positive behavior that can support the organization such as job satisfaction, organizational commitment, in-role performance, and extra-role performance (Hsiao and Chen, 2012).

The Covid-19 pandemic that hit Indonesia in early 2020 until now has caused disruption which changed employment practices across the nation. Previous study examines how organizations respond to the pandemic and how to adapt human resource practices to the new normal (Gigauri, 2020). Studies have shown changes in HR policies can overcome challenges by practicing work from home, flexible hours, and employee wellbeing (Gigauri, 2020). Another study implicated that "negative career shocks have long-term positive consequences for some people" (Akkermans et al., 2020). As another study considers the challenges of career development during Covid-19 using Meta-theoretical Systems Theory Framework and its applications of system thinking and system mapping (McMahon, 2020).

The purpose of this study is to see the perception of employees pursuing a career in an organization will be met by the view of the extent to which their personal needs and interests can be met. This is what then underlies a person's decision to stay and survive in the organization or must move to another organization that can better ensure the fulfillment of these needs and interests.

\section{RESEARCH METHODS}

This research uses questionnaires for data collection. The questionnaire was distributed to respondents using Google Form. Samples were collected based on demographic criteria including gender, age, working status, and duration of employment. In addition, respondents must be employed for a minimum of one year, work in Makassar, South Sulawesi, aged between 23 to 70 years old, and work either in the banking industry, private organization, a government-owned organization (BUMN), business owner, or laid off as an impact of the pandemic.

Since the population is large and it is not known with certainty, in determining the ideal and representative number of respondents for this research, Hair et al. (2010) state that the number of good and ideal respondents is based on the number of indicators of all variables multiplied by 5-10. In this study, there were 13 indicators from 2 variables to be examined in this study. So based on the number of indicators it can be determined the minimum number of respondents in this study is 65 people while the maximum number is 130 people. Overall, 72 respondents have participated in this study.

Bivariate analysis is used to test the hypothesis in this study and to see the relationship between the independent variable and the dependent variable. To see this relationship. Chi-Square is a type of non-parametric comparative test using two variables. The proposed hypothesis is $H_{1}$ : Career planning has a significant effect on career management.

The two variables to be tested in this study are career planning and career management. Career planning involves several indicators that are useful to individuals as information in their career development, such as: determining who you are, how you are viewed, investigating options, creating an overall plan, and taking action to advance plan (Mathis et al., 2017). Whereas, career management indicators are: data gathering, feedback, goal setting, action planning, and follow-up (Noe et al., 2016).

\section{RESULT AND DISCUSSION}

A total of 72 respondents take part in this study ranging in gender, age, and occupation. According to the survey, as many as $26(36.1 \%)$ respondents were male and $46(63.9 \%)$ were female aged between 23 to 60 years old. Survey also shows respondents working in diverse occupations. Individuals who worked in the banking industry approximately 29.1 percent $(n=21)$, in private organizations 38.9 percent $(n=28)$, government owned organizations (BUMN) 18.1 percent $(n=13$, and business owners 13.9 percent $(n=10)$.

Furthermore, 48.6 percent $(n=35)$ of respondents have changed employment for various reasons. In this case, individuals feel their previous employment does not fit either their interest 37.1 percent, skills 2.9 percent, personality 17.1 percent, or work values 42.9 percent. As Mathis et al. (2017) argue that it is useful for individuals to have a starting point in career planning by assessing interest, skills, personality, and work values which reflect his or her unique characteristics that will help individuals determine the type of career to pursue. Employees need to design his or her career path to achieve successful career planning (DeCenzo et al., 2016).

Based on the data shown in Table 1, most respondents 79.7 percent agree with most statements of career planning in correlation with career management, even though 20.3 percent disagree. This result shows the p-value of the variables studied are not independent of one another which means there is a statistically significant relationship between the variables.

Further discussion will be based on questionnaire data collected. Survey shows respondents mostly in agreement that to achieve a successful career in the future, individuals must find information regarding how their boss and co-workers view his or her capabilities at work. Individuals who are engaged in developing their career competencies will be more likely to have 
Table 1: Cross Tabulation of Career Planning and Career Management

\begin{tabular}{|c|c|c|c|c|c|}
\hline & & & \multicolumn{2}{|c|}{ Career Management } & \multirow{2}{*}{ Total } \\
\hline & & & Agree & Disagree & \\
\hline \multirow{8}{*}{$\begin{array}{l}\text { Career } \\
\text { Planning }\end{array}$} & \multirow{4}{*}{ Agree } & Count & 47 & 12 & 59 \\
\hline & & Expected Count & 41.8 & 17.2 & 59.0 \\
\hline & & $\%$ within Career Planning & $79.7 \%$ & $20.3 \%$ & $100.0 \%$ \\
\hline & & $\%$ within Career Management & $92.2 \%$ & $57.1 \%$ & $81.9 \%$ \\
\hline & \multirow{4}{*}{ Disagree } & Count & 4 & 9 & 13 \\
\hline & & Expected Count & 9.2 & 3.8 & 13.0 \\
\hline & & $\%$ within Career Planning & $30.8 \%$ & $69.2 \%$ & $100.0 \%$ \\
\hline & & $\%$ within Career Management & $7.8 \%$ & $42.9 \%$ & $18.1 \%$ \\
\hline \multirow{4}{*}{\multicolumn{2}{|c|}{ Total }} & Count & 51 & 21 & 72 \\
\hline & & Expected Count & 51.0 & 21.0 & 72.0 \\
\hline & & $\%$ within Career Planning & $70.8 \%$ & $29.2 \%$ & $100.0 \%$ \\
\hline & & $\%$ within Career Management & $100.0 \%$ & $100.0 \%$ & $100.0 \%$ \\
\hline
\end{tabular}

Source: Research computation

Table 2: Chi-Square Tests

\begin{tabular}{lrrlll}
\hline & Value & df & $\begin{array}{l}\text { Asymptotic } \\
\text { Significance } \\
\text { (2-sided) }\end{array}$ & $\begin{array}{l}\text { Exact Sig. } \\
\text { (2-sided) }\end{array}$ & $\begin{array}{l}\text { Exact Sig. } \\
\text { (1-sided) }\end{array}$ \\
\hline Pearson Chi-Square & 12.326 & 1 & .000 & & \\
Continuity Correction & 10.073 & 1 & .002 & .001 & .001 \\
Likelihood Ratio & 11.278 & 1 & .001 & \\
Fisher's Exact Test & & & & .000 & \\
Linear-by-Linear Association & 12.154 & 1 & .000 \\
N of Valid Cases & 72 & & & & \\
\hline Source: Research computation & & &
\end{tabular}

Source: Research computation

a positive career (Akkermans et al., 2020). Indeed, DeCenzo et al. (2016) also point out that a manager's role in mentoring employees is key in helping individuals achieve career goals. Mentoring employees can offer insights into how individuals can develop their careers. Good managers assist employees to develop their strengths and minimize sources of weaknesses and give continuous feedback on their performance (Snell and Bohlander, 2013). Previous research found that 52 percent of managers help employees improve their skills even during the Covid-19 pandemic (Gigauri, 2020). Not just managers, coworkers may also be a good mentors especially when they have the experience and advanced skill set needed by the employee (DeCenzo et al., 2016).

Moreover, respondents concur that they are willing to discuss their career planning with their supervisor/manager, attend seminars, continuing education, or get involved with projects to develop their career. Taking action to advance in individual career planning is a crucial step (Mathis et al., 2017). As further explained, once an individual has gained experience and skills needed for career development, then periodic evaluation of career goals is required.

Respondents in this study feel responsible for identifying career opportunities and improving their knowledge and skills. This means employees need to know their career motives and expectations (DeCenzo, Robbins, Verhulst, 2016). However, they also claimed that their career planning had changed ever since the Covid-19 pandemic. An earlier study done by Baert et al. (2020)found that some Belgian employees are concerned they will miss out on promotional opportunities because of the pandemic.

To test the hypothesis of this research, quantitative data analysis Chi-Square is used. The Chi-Square test has verified that there is a significant relationship between career planning and career management with a p-value of 0.00 which is less than 0.05. While most respondents agree with the particular statement(s) in career planning in correlation with career management, some are in disagreement with the particular statement(s) in career planning and career management. This indicates the p-value of the two variables are not independent of one another and has proven there is a statistically significant relationship between the variables.

\section{CONCLUSION}

It can be concluded this study examined the relationship between career planning and career management. Individuals are responsible to know their strengths, weaknesses, interests, 
skills, personality, and work values. At the same time, organizations must provide career development opportunities for employees to grow and succeed.

Limitations to this study are: (a) this study is conducted in a limited time frame and therefore researchers are unable to gather a larger sample, and (b) further research is needed with a larger sample and more in-depth analysis.

\section{References}

Akkermans, J., Richardson, J., Kraimer, M. L., 2020. The Covid-19 Crisis as a Career Shock: Implications for Careers and Vocational Behavior. Journal of Vocational Behavior 119, 1-5.

URL: http://doi.org/10.1016/j.jvb.2020.103434

DOI: $10.1016 / j \cdot j v b .2020 .103434$

Baert, S., Lippens, L., Moens, E., Sterkens, P., Weytjens, J., 2020. How Do We Think the Covid-19 Crisis Will Affect Our Careers (If Any Remain)? IZA Institute of labor Economics, Germany.

URL: https://ftp.iza.org/dp13164.pdf

DeCenzo, D. A., Robbins, S. P., Verhulst, S. L., 2016. Fundamentals of Human Resource Management, 12th ed. John Wiley Sons, New Jersey.

George, J. M., Jones, G. R., 2012. Understanding and Managing Organizational Behavior, 6th ed. Prentice Hall, New Jersey.

Gigauri, I., 2020. Challenges HR Managers Facing due to COVID-19 and Overcoming Strategies: Perspectives from Georgia. Archives of Business Research $8(11), 1-18$.

URL: http://doi.org/10.14738/abr.811.9313

Hair, J., Black, W., Babin, B., Anderson, R., 2010. Multivariate Data Analysis. Always learning. Prentice Hall.

URL: https://books.google.co.id/books?id=JlRaAAAAYAJ
Hamouche, S., 2021. Human Resource Management and The COVID-19 Crisis: Implications, Challenges, Opportunities, and Future Organizational Directions. Journal of Management Organization, 1-16.

Hsiao, J.-M., Chen, Y.-C., 2012. Antecedents and Consequences of Job Satisfaction: A Case of Automobile Component Manufacturer in Taiwan. The International Journal of Organizational Innovation, 164-174.

ILO, 2021. COVID-19 and the World of Work.

URL: https://www.ilo.org/global/topics/coronavirus/ lang--en/index.htm

Mathis, R. L., Jackson, J. H., Valentine, S. R., Meglich, P. A., 2017. Human Resource Management, 15th ed. Cengage Learning, Boston.

McMahon, M., 2020. The Systems Theory Framework and Career Development in a Covid-19 Context. Indian Journal of Career and Livelihood Planning 9 (1), 3-12.

Noe, R. A., Hollenbeck, J. R., Gerhart, B., Wright, P. M., 2016. Fundamental of Human Resource Management, 7th ed. McGraw-Hill Education, New York.

OECD, 2021. An assessment of the impact of COVID-19 on job and skills demand using online job vacancy data.

URL: https://www.oecd.org/coronavirus/policy-responses/ an-assessment-of-the-impact-of-covid-19-on-job-and-demand-using-online-job-vacancy-data-20fffo9e/

Page, M., 2015. Indonesian employees confident in the job market. URL: http://michaelpage.co.id/advice/ market-insights/industry-reports/ indonesian-employees-confident-job-market

Robbins, S. P., Judge, T. A., 2017. Organizational Behavior, 17th ed. Pearson Education, Boston.

Snell, S., Bohlander, G., 2013. Managing Human Resources, 16th ed. SouthWestern, Cengage Learning, Mason.

Weng, Q., McElroy, J. C., 2010. Vocational self-concept crystallization as a mediator of the relationship between career self-management and job decision effectiveness. Journal of Vocational Behavior, 234-243.

URL: https://doi.org/10.1016/j.jvb.2009.10.012 